\title{
Vibrio nigripulchritudo monitoring and strain dynamics in shrimp pond sediments
}

\author{
E. Walling ${ }^{1}$, E. Vourey ${ }^{1}$, D. Ansquer ${ }^{1}$, B. Beliaeff ${ }^{1}$ and C. Goarant ${ }^{2,{ }^{*}}$
}

\author{
${ }^{1}$ IFREMER, Station d'Aquaculture de Saint-Vincent, Noumea Cedex, New Caledonia \\ ${ }^{2}$ Laboratoire de Recherche en Bactériologie, Institut Pasteur de Nouvelle-Calédonie, Noumea, New \\ Caledonia \\ *: Corresponding author : C. Goarant, email address : cgoarant@pasteur.nc
}

\begin{abstract}
:
Aims: A description of bacterial pathogens in shrimp ponds is necessary to understand their pathogenesis. Vibrio nigripulchritudo was shown to contain saprophytic and pathogenic strains among New Caledonian isolates. We established a method to map the development of $V$. nigripulchritudo in pond sediments at three different genetic levels: the species level, then at the pathogenic cluster level and finally at the plasmid level, present only in all highly pathogenic isolates.
\end{abstract}

Methods and Results: PCR methods were applied to shrimp pond sediments both before and after a mortality outbreak. Using crude samples, the species $V$. nigripulchritudo is not detected at first $(0 / 42$ samples at day 56 post stocking) but appears frequently in the sediments after the mortality event (30/42 at day 107). The distribution of strains from the pathogenic cluster of $V$. nigripulchritudo also follows this pattern. In contrast, the pSFn1 virulence-associated plasmid was detected in one sample at day 56 and none at day 107. An enrichment method was developed to lower the detection limits of our assays. After enrichment, the species $V$. nigripulchritudo was detected in all samples at both dates. The number of samples positive for pSFn1 was 42/42 samples at day 56 and 29/42 at day 107 .

Conclusions: These results show that the sediments contain $V$. nigripulchritudo, notably pathogenic strains. Surprisingly, the virulence-associated plasmid pSFn1 found in all V. nigripulchritudo isolated from moribund shrimp appears less frequently in sediments, possibly being useless or even detrimental to its recipient bacteria in this environment.

Significance and Impact of the Study: This study confirms the presence of pathogenic $V$. nigripulchritudo strains in shrimp pond sediment before a mortality outbreak complying with a previous hypothesis that sediments could be the infecting reservoir. After the outbreak, both total $V$. nigripulchritudo and pathogenic strains populations have largely increased, possibly contributing to the recurrent mortality observed in this shrimp vibriosis.

Keywords: detection $\bullet$ diagnosis $\bullet$ diseases $\bullet$ ecology $\bullet P C R \cdot$ plasmids $\bullet$ soil $\bullet$ virulence 


\section{Introduction}

In New Caledonia, located in the South Pacific Ocean, shrimp pond farming is based on the culture of the domesticated Pacific blue shrimp Litopenaeus stylirostris. Since 1980 production has increased from nonexistent to a total of about 2000 tons per year (Institut de la statistique et des études économiques, www.isee.nc). Although the production is small compared to the world shrimp production (2.6 million tons for penaeid shrimp, www.ifremer.fr/aquaculture), in New Caledonia this industry is the second export business on the island. However, shrimp aquaculture in New Caledonia can be threatened by disease outbreaks.

Two seasonal vibrioses regularly affect shrimp populations and can cause severe mortalities in specific environmental conditions (Mermoud et al., 1998; Goarant et al., 2006a). Since the use of antibiotics in ponds has been banned in New Caledonian farming procedures (Andrier, 2003), fighting against bacterial diseases solely depends on prophylaxis. Therefore, studies on the pathogenic Vibrio species were undertaken to find ways to decrease the risk of disease and disease spread (Goarant et al., 2006b).

An emerging cluster of highly pathogenic Vibrio nigripulchritudo has been identified as the etiological agent for Summer Syndrome (Goarant et al, 2006a, b). This Vibrio species was also recently reported in mass mortality outbreaks in Marsupenaeus japonicus in Japan (Sakai et al., 2007). In New Caledonia, this disease occurs during the warm season and as of 2007, it affects 3 out of 17 farms of New Caledonia and can wipe out as much as $80 \%$ of the shrimp population in a pond around day 55-60 of the 120-day grow out period (Lemonnier et al., 2006). The profitability of the farms struck by the disease is threatened by the recurrent mortalities induced by $V$. nigripulchritudo. The risk of disease outbreak depends on interdependent parameters such as environment quality (Kautsky et al., 2000; Lemonnier et al., 2006), shrimp physiology (Wabete et al., 2008) and bacterial virulence which was shown to be strain-specific within the species V. nigripulchritudo (Goarant et al, 2006a).

Genotype analysis of a collection of strains allowed the identification of a cluster of strains identified by AP-PCR and MLST that contains all highly pathogenic isolates (Goarant et al, $2006 \mathrm{~b}$ ). This suggested that virulence can be predicted using genetic markers. To investigate the genetic basis of virulence, subtractive hybridization (SSH) experiments were undertaken between a highly pathogenic tester strain $V$. nigripulchritudo and a non pathogenic driver strain V. nigripulchritudo (Reynaud et al., 2008). Sixty eight SSH fragments were detected in all virulent strains and within these 68 fragments, 13 were restricted to the most virulent strains. Of these 13 markers, 10 are localized on an 11237 bp plasmid named pSFn1 that possibly carries virulence determinants. Because it is consistently associated to high virulence in New Caledonian V. nigripulchritudo strains (Reynaud et al., 2008), it can be regarded as a virulence marker.

Sediments have been suggested to be a potential reservoir of these pathogenic Vibrio (Goarant et al. 2006a) as was already described for other Vibrios (Kaneko and Colwell, 1978), including fish or shrimp pathogens (Enger et al, 1989 ; de la Peña et al., 1992). This study aims at describing the bacterial dynamics in pond sediments by mapping total heterotrophic bacteria and $V$. nigripulchritudo at the species and strain levels with both molecular and culture-dependent techniques.

\section{Materials and method}

\section{Experimental grow out and shrimp analysis}

The pond used in this study covers $1520 \mathrm{~m}^{2}$. Water was first pumped in on august 15, 2007 and a week later, postlarvae (PL) were used to stock the pond at a density of $18.2 \mathrm{PL} . \mathrm{m}^{-2}$ (day 1). Water renewal and feeding followed the usual rearing procedures as described 
elsewhere (Lemonnier et al., 2006) and a total of $300 \mathrm{~kg}$ of feed was distributed over the whole rearing period. Moribund shrimp were collected and analyzed as previously described (Goarant et al., 2006). Briefly, one drop of haemolymph aseptically withdrawn from the ventral sinus was plated on solid Marine Agar with 2\% glycerol (weight/volume) and incubated at $30^{\circ} \mathrm{C}$ for 72 hours. Putative $V$. nigripulchritudo colonies were identified as black colonies in the presence of glycerol.

\section{Sediment sampling and analysis}

Pond sediments were collected at 42 points in staggered rows with two $50-\mathrm{mL}$ core samplers. For each point, two 3-cm deep sediment cores were collected underwater and transported to the laboratory within 15 minutes.

Immediately after sampling, temperature and $\mathrm{pH}$ were measured using a Hanna instrument pocket thermometer and an IQ Scientific field $\mathrm{pH}$ meter. Sediment dry weight was determined by measuring the weight loss after drying at $60^{\circ} \mathrm{C}$ for 5 days in a Memmert oven. Ash free dry weight was measured for an estimation of organic matter content by burning the dried sediments for 5 hours at $550^{\circ} \mathrm{C}$ in the oven. Chloroplastic pigment concentration was calculated using the spectrophotometric method, after acetone extraction, from the equations of Lorenzen and Jeffrey (1980) for chlorophyll a, b and c.

Sediments were also artificially inoculated with known concentrations of $V$. nigripulchritudo as positive controls.

\section{Bacterial strains, media and DNA extraction}

Vibrio strains used in this study are listed in tables I and II. All the strains isolated in New Caledonia are deposited in the bacterial pathogen collection for marine aquaculture species (Centre de Ressources Biologiques, Laboratoire de Génétique et Pathologie, Institut Français de Recherche pour l'exploitation de la MER, La Trembalde, France, www.ifremer.fr/crb). DNA from bacterial Marine broth cultures was purified using the High Pure $^{\mathrm{TM}}$ PCR Template Preparation kit (Roche Diagnostics). DNA from sediments was isolated using the PowerSoil ${ }^{\mathrm{TM}}$ DNA Isolation Kit from MO BIO Laboratories following the manufacturer's instructions.

For total heterotrophic bacteria and presumptive Vibrio nigripulchritudo identification, serially diluted wet sediments were spread on solid Marine Agar supplemented with 2\% (weight/volume) glycerol (Baumann and Schubert, 1984). The enrichment solution was marine broth diluted $1 / 2$ with sterile artificial sea water. Sediments to be enriched $(5 \mathrm{~g}$ of wet sediments in $10 \mathrm{~mL}$ enrichment solution) were incubated 24 hours at $28^{\circ} \mathrm{C}$ with constant agitation (120 rpm). Then, DNA was extracted as described above.

\section{PCR}

Amplifications were done in an AppliedBiosystem 9700 thermal cycler for routine PCR and in a Roche LightCycler ${ }^{\circledR}$ 2.0 Carousel-Based System for real time PCR. The following primers were used for universal 16S rDNA amplification CTCAGATTCAACGCTGGCGG and GGCGGTGTGTACAAGGCCCG, for $V$. nigripulchritudo species characterization, $V n F$ and VR with an annealing temperature of $58^{\circ} \mathrm{C}$ (Goarant et al., 2006a).

For plasmid pSFn1 detection, primers pSFn1-6020 and pSFn1-6974 were designed using the Primer3 software from a previously published sequence of pSFn1 (accession number EU156059, Reynaud et al., 2008) and had the following sequences pSFn1-6020 TGTCTTCTGGATCGCTTCGCC and pSFn1-6974 CGTCGTAAGGAGCGATAAGCC (annealing temperature $55^{\circ} \mathrm{C}$ ), generating a specific 954-bp long amplicon. Reagents (polymerase and buffers) were from QIAGEN and used following the manufacturer's protocol. 
The "Summer syndrome" emerging cluster of pathogenic strains was identified and quantified in sediment DNA samples using real time PCR with hybridization probes targeting a particular polymorphism in gyrB as previously described (Goarant et al., 2007).

Universal 16S amplification was used as an internal amplification control when PCR results were negative with the other primers.

\section{Statistical analysis and maps}

Statistical analysis including mapping was done using the S-PLUS software (Seattle, WA, USA). Bacteria means were compared using t-tests at a $5 \%$ signification threshold after logtransformation.

\section{Results}

\section{General pond evolution during the study}

Shrimp were harvested on December 11, 2007 after 112 days of grow out. Final survival was $58 \%$ and shrimp mean individual weight was $9.75 \mathrm{~g}$. On days 89 and 95, one and 12 moribund shrimp were observed and collected for analysis respectively. V. nigripulchritudo septicemia was confirmed as the etiological cause of the mortality of these shrimp, all haemocultures displaying a heavy monomorphous colonization by $V$. nigripulchritudo. Typical Summer Syndrome was confirmed using the genetic tools available (AP-PCR and plasmid pSFn1-specific PCR) on cultivated isolates.

Mean chemical and physical parameters of the pond are presented in table III. During the production cycle, mean temperature increased from $23.8^{\circ} \mathrm{C}$ to $29.7^{\circ} \mathrm{C}$, reaching the critical $28^{\circ} \mathrm{C}$ known to enhance the risks of Summer Syndrome (Lemonnier et al., 2006). The overall $\mathrm{pH}$ of the sediments went from 7.15 to 6.87 suggesting an overall acidification of the sediments. Other sediment quality parameters (ash free dry weight and water content) were stable over the production period. Chlorophyll concentration was highly variable.

\section{Plasmid pSFn1 PCR specificity and PCR detection limits}

Eleven species of Vibrio and 34 strains of Vibrio nigripulchritudo were used to check the specificity of the primers designed. No amplification was generated when using template DNA from strains belonging to a different species than $V$. nigripulchritudo. DNA from V. nigripulchritudo strains known to carry the plasmid pSFn1 (Reynaud et al., 2008) systematically generated an amplicon at the expected size, 954 bp (Table II, SFn1 group, $\mathrm{n}=$ 6.) Other strains with the summer syndrome genotype and known to be highly pathogenic also generated a 954-bp product with the plasmid specific PCR (Table II, Fn13 group, $n=4$ ). DNA from strains described as moderately pathogenic did not generate any amplicon (Table II, BDn1 group, $\mathrm{n}=8$ ). All the strains with a different genotype than the summer syndrome genotype were negative with the pSFn1 specific PCR, whether moderately or non virulent (Table II, SO65 group, $\mathrm{n}=5$ and SFn118 group, $\mathrm{n}=11$ ). Virulent strains with the summer syndrome genotype can now be distinguished as pSFn1-carriers or non-carriers. The technique was then optimized for the analysis of sediment samples.

It was shown previously that the TCBS medium specific of Vibrio is not suitable for the detection of $V$. nigripulchritudo because this species grows poorly on this medium. Therefore, Marine agar supplemented with $2 \%$ glycerol is used, but this medium is not selective. For $V$. nigripulchritudo colonies to be detected on this medium from sediment samples, they need to be sufficiently concentrated and not overshadowed by the other colonies. Our results indicate 
that the detection limit for presumptive $V$. nigripulchritudo on Marine Agar is $10^{3} \mathrm{CFU} . \mathrm{g}^{-1}$ wet sediment weight.

Using a V. nigripulchritudo species specific PCR on crude sediments inoculated with decreasing quantities of $V$. nigripulchritudo, the detection limit was also found to be $10^{3}$ CFU. ${ }^{-1}$ wet weight. The same samples were used to evaluate the detection limit of the pSFn1 specific PCR that was about $10^{6} \mathrm{CFU} \cdot \mathrm{g}^{-1}$ wet sediment weight.

Using DNA from enriched sediments samples allowed lowering the detection limits to about $100 \mathrm{CFU} \cdot \mathrm{g}^{-1}$ wet weight for both $V$. nigripulchritudo species specific and pSFn1 virulence marker PCRs.

\section{Sediment total heterotrophic flora (THF)}

Between both sampling dates, cultivable THF is comparable $\left(5.1310^{7} \mathrm{CFU} \cdot \mathrm{g}^{-1}\right.$ and $3.2410^{7}$ CFU. $\mathrm{g}^{-1}$ ) At the first sampling date, no spatial variability is evidenced in terms of THF (figure 1). At the second sampling date, THF is slightly higher in the center of the pond and towards the lower part near the water exit station.

\section{Vibrio nigripulchritudo detection in sediment at different genetic levels}

At the species level, the number of sediment sample cultures presenting black colonies was 26/42 at D56 before the outbreak, and 37/42 at D107 after the mortality outbreak (days 8995, figure 1). Direct PCR detection of the species went from 0/42 to 30/42 positive sediment samples (figure 2). Analysis of sediments after enrichment reveals that all samples are positive at day 56 and 107 (figure 3).

At the emerging "Summer Syndrome" cluster level, the sediment samples were screened for this cluster by real time PCR using the method described previously (Goarant et al., 2007). Using the standard curve established previously, the detection limit for this assay is 100 inoculated CFU. $\mathrm{g}^{-1}$ wet weight. Before the outbreak (D56), only one sample proved positive for this cluster whereas 36/42 points were found positive after the outbreak (D107) (figure 2). Samples with the highest concentration of V. nigripulchritudo with the "Summer Syndrome" genotype $\left(>4.10^{3}\right.$ CFU. $g^{-1}$ wet weight) do not follow a particular spatial pattern in the pond (figure 4). Highly concentrated samples (as represented by black squares in figure 4) are spread over the entire pond area. Some samples are positive with the species PCR and negative for the pathogenic cluster. More surprisingly, some samples are positive for the pathogenic cluster but are negative with the species PCR.

At the plasmid level with direct PCR, only one sample was positive at D56 and none at D107 (figure 2). To lower the detection limit with this PCR technique $\left(10^{6} \mathrm{cfu} \cdot \mathrm{g}^{-1}\right.$ wet weight), an enrichment step was added before DNA purification from sediments. Heterotrophic bacteria carrying pSFn1 and present at low concentrations in the sediments can be detected by PCR after enrichment, subject to the fact that the bacteria are cultivable in the enrichment medium. With PCR on enriched sediments, all the samples were positive at D56, but at D107, only 29/42 points were positive (figure 3).

\section{Discussion}

To understand how the environment can influence pathogen development in ponds, several parameters were measured on 42 samples of an experimental grow out pond. A "Summer 
Syndrome" mortality outbreak caused by HP V. nigripulchritudo occurred and one sampling survey could be conducted both before and after this outbreak. At both dates, we used both culture-dependant and molecular techniques to characterize $V$. nigripulchritudo strains in the sediments in order to circumvent the limits of each technique: lack of specificity for culturedependant techniques, high detection limit for direct PCR, lack of quantification for enriched PCR. Specific PCR assays were used to identify the etiological pathogen at different genetic levels. Techniques described previously allowed the identification of $V$. nigripulchritudo at the species level and at the level of the cluster that contains all Summer Syndrome HP isolates (Goarant et al., 2006b and 2007). Lastly, a plasmid PCR assay targeting pSFn1 developed here was used both to study pathogen dynamics in the farming environment during production and to confirm the identification of the etiological agent of the outbreak. Because plasmids are mobile genetic elements, we checked and validated that our assay failed to amplify any product from non- $V$. nigripulchritudo strains or from $V$. nigripulchritudo strains with no or only moderate virulence to shrimp. Though not isolated, some strains could carry the plasmid but not the chromosomic background necessary for virulence expression. Therefore, it is useful to analyze both the genotype (based on a chromosomal gene polymorphism) and the presence of pSFn1 in newly isolated strains and check that they belong to the Summer Syndrome emerging genotype. Because plasmids may be lost in subcultures, we also checked the stability of pSFn1 which could be identified in cultures after more than 15 passages (our unpublished results).

When analyzing the results from all the techniques used together in this study, a picture of $V$. nigripulchritudo strains dynamics in sediments at two phases of the production cycle can be suggested.

Total Heterotrophic cultivable Flora was shown to be more concentrated in the center of the pond, especially at the end of the rearing period (figure 1). This is consistent with the results of Burford et al (1998) and the ones of Delgado et al (2003) on ponds equipped with aerators showing that THF was significantly more concentrated in the pond center, where sludge had accumulated. Delgado and coll. also demonstrated a pH decrease as observed in our study ; Burford and coll. also showed that bacterial numbers were correlated with organic carbon and nitrogen content. Similarly, aquaculture-influenced sediments were shown to harbor high levels of Vibrio compared to surrounding areas in other systems, either fish (Enger et al., 1989) or mollusks (La Rosa et al., 2001). Culture on Petri dishes showed that putative $V$. nigripulchritudo colonies were present at the first sampling date and spread around the outskirts of the pond. This fact is interesting since this area was shallower and the environmental conditions could be different in terms of light exposure, oxygen content, and nutrient concentration, leading to a different colonization dynamics by benthic organisms. Vibrio are known to have an affinity for phytoplankton and it was shown that Vibrio cholerae developed in environments favorable to algae, cyanobacteria, and aquatic plants (Pruzzo et al., 2005). Similar results were obtained by Eiler and colleagues (2007) who demonstrated that cyanobacterial by-products largely influenced Vibrio population growth in mesocosms. Early studies evidenced this trophic association and pointed out its interest as an explanation to pathogen persistence (Tamplin et al., 1990 ; Epstein et al., 1993 ; Islam et al., 1994). This particular affinity between Vibrios and planktonic food chains was also studied in more details in recent large scale studies (Lipp et al., 2002), including environmental sensing for epidemics prediction (Hsieh et al., 2008 ; Constantin de Magny et al., 2008).

Theoretically, the detection limits for putative $V$. nigripulchritudo colonies on Petri dishes and for identification at the species level with direct PCR are both around $10^{3}$ CFU.g ${ }^{-1}$ wet sediment weight. However, in use, culture-dependant detection seems to be more sensitive but has major drawbacks: cells need to be in a cultivable state, presumptive phenotypic identification based on the sole expression of a pigment can suffer a lack of specificity, plates tend to be overcrowded by the THF and black colonies are difficult to isolate. Lastly, because $V$. nigripulchritudo contains both saprophytic and pathogenic strains, culture-dependant detection leaves some uncertainty.

At the first sampling date, D56 of the grow out period, a population of pSFn1-carrying bacteria as well as bacteria belonging to the species $V$. nigripulchritudo are evidenced over 
the entire pond sediments by PCRs from enriched sediment samples. These bacteria were not easily detected by direct PCRs that only detect populations above $10^{3} \mathrm{CFU} \cdot \mathrm{g}^{-1}$ (for the species) or $10^{6} \mathrm{CFU} \cdot \mathrm{g}^{-1}$ (for the plasmid), demonstrating their relatively low level. One sample was nevertheless positive for the plasmid, and another one was positive for the emerging genotype, possibly indicating that some sediment areas support high concentrations of HP V. nigripulchritudo, even before the mortality event. Sediments could therefore actually be the source of infection, as hypothesized by Goarant et al (2006a).

Why these sediment samples were not positive with the species-specific direct PCR remains unknown: this could be a technical artifact due to heterogeneity in DNA extraction or difference in PCR efficiencies. Alternatively and though pSFn1 was never evidenced from any other bacterial species, pSFn1 or a highly similar plasmid could possibly be present in non- $V$. nigripulchritudo bacteria in our experimental pond.

At the second sampling date, D107 of the production cycle, which is close to the end of the 112-day rearing period, the sediments were colonized by $V$. nigripulchritudo, including strains with a genotype identical to that of the emerging cluster, as evidenced by the results obtained with direct PCR (figure 2). This shows that over time, the proportion of bacteria from the species $V$. nigripulchritudo including those of the emerging genotype increased. Between the two sampling dates and possibly related to the mortality event, the sediments were colonized by the $V$. nigripulchritudo strains, reaching concentrations above the detection limit of direct PCR. Again, some samples proved positive for the emerging genotype but not for the species, most probably because of the differences in detection limits between classic PCR used for species characterization and real time PCR used for genotype quantification (a one-log factor).

Surprisingly, bacteria harbouring the plasmid pSFn1 were less frequently found in the sediments at this sampling date, after the mortality event, even though both the species $V$. nigripulchritudo and the pathogenic cluster were shown to colonize the sediments. Culturebased evaluation of $V$. nigripulchritudo populations confirms that this species tends to colonize the sediments during the production cycle.

Despite the overall colonization of the sediments by strains of $V$. nigripulchritudo, and the very high production of pSFn1-harbouring strains during the mortality event, the detection of pSFn1-carrying bacteria was not increased at the second sampling date. Furthermore, plasmid detection with PCR after sample enrichment was more difficult than at the first sampling date. This is unexpected since the species and emerging genotype were both detected at higher concentrations at the second sampling date with either direct or enriched PCR. Though a bias can possibly result from enrichment procedures, enriched PCR results suggest that highly pathogenic strains carrying the plasmid are not as frequent at D107 than at D56. We hypothesize that this plasmid could constitute a metabolic burden in the late pond environment. In contrast, highly virulent strains carrying pSFn1 are constantly isolated from moribund shrimp during Summer Syndrome outbreaks, suggesting that this plasmid confers a selective advantage in diseased shrimp and is actually related to virulence, as suggested by Reynaud et al. (2008). We make the hypothesis that the selection of highly pathogenic strains takes two steps: first, V. nigripulchritudo from the Summer Syndrome emerging genotype are selected in the eutrophic pond environment and second a subpopulation of cells from this genotype carrying the plasmid are selected in weakened shrimp as another ecological niche. Should this hypothesis be later confirmed, this would illustrate how genomic diversity and horizontal gene transfer allow the selection of the fittest strains in any specific environment even though that environment might be changing and new ecological niches might appear (Hacker et al., 2004). 
Since there are no means to eliminate bacterial pathogens directly in ponds, knowledge on pathogenic strain dynamics during grow-out and dry-out periods could lead to methods to limit pathogen development in sediments. Because of the high diversity in virulence capacity of $V$. nigripulchritudo among New Caledonian isolates, molecular tools targeting the etiological agent of Summer Syndrome had to be improved. Highly pathogenic (HP) $V$. nigripulchritudo all belong to the same emergent cluster. However, this cluster contains both HP strains and moderately pathogenic (MP) strains (Goarant et al., 2006b) and HP strains can only be distinguished from MP strains by the presence of the PSFn1 plasmid, regarded as a virulence marker (Reynaud et al., 2008). The PCR assay targeting this plasmid developed here allows, together with a genotype-specific PCR assay, to evaluate the risk of Summer Syndrome in New Caledonian shrimp aquaculture. Further studies will study the occurrence of $V$. nigripulchritudo populations after the harvest and during the dry out period.

\section{Acknowledgements}

We are extremely grateful to A. Collet, L. Della Patrona, R. Lucas, A.-L. Marteau, J. Patrois, and J.M. Peignon, for their assistance with sample collection. This study would not have been possible without the valuable support of the husbandry staff working on the experimental farm in Saint Vincent, New Caledonia. Thanks are due to Dr F. Le Roux for providing a critical review of the manuscript.

Funding for the scientific program, DEDUCTION, was provided by IFREMER, the New Caledonian government and Provincial institutions.

\section{References}

Andrier, P. (2003) Une vision globale de l'aquaculture de crevettes et son marché. In Styli 2003 Trente ans de crevetticulture en Nouvelle-Calédonie. Ed. Goarant, C., Harache, Y., Herbland, A. and Mugnier, C. pp.18-22, Actes de Colloques Ifremer $n^{\circ} 38$.

Boyd, C.E. (1995) Bottom soils, sediments and pond aquaculture. Ed. Chapman, Hall, New York, USA.

Burford, M.A., Peterson, E.L., Baiano, J.C.F. and Preston, N.P. (1998) Bacteria in shrimp pond sediments and their role in mineralizing nutrients and some suggested sampling strategy. Aquac. Res. 29, 843-849

Constantin de Magny, G., Murtugudde, R., Sapiano, M.R., Nizam, A., Brown, C.W., Busalacchi, A.J., Yunus, M., Nair, G.B., Gil, A.I., Lanata, C.F., Calkins, J., Manna, B., Rajendran, K., Bhattacharya, M.K., Huq, A., Sack, R.B., and Colwell, R.R. (2008) Environmental signatures associated with cholera epidemics. Proc Natl Acad Sci U S A. 105, 17676-81.

de la Peña, L. D., Momoyama, K., Nakai, T., and Muroga, K. (1992) Detection of the causative agent of vibriosis in kuruma prawn, Penaeus japonicus. Fish Pathology - Gyobyo Kenkyu 244, 223-228.

Delgado, P. C., Y. Avnimelech, R. McNeil, D. Bratvold, C. L. Browdy, and P. Sandifer. (2003). Physical, chemical and biological characteristics of distinctive regions in paddlewheel aerated shrimp ponds. Aquaculture 217, 235-248.

Eiler, A., Gonzalez-Rey, C., Allen, S., and Bertilsson, S. (2007) Growth response of Vibrio cholerae and other Vibrio spp. to cyanobacterial dissolved organic matter and temperature in brackish water. FEMS Microbiol Ecol. 60, 411-418. 
Enger, O., Husevåg, B., and Goksøyr, J. (1989) Presence of the fish pathogen Vibrio salmonicida in fish farm sediments. Appl Environ Microbiol. 55, 2815-2818.

Epstein, P.R. (1993) Algal blooms in the spread and persistance of cholera. Biosystems 31, 209-221.

Goarant, C., Ansquer, D., Herlin, J., Domalain, D., Imbert, F. and De Decker, S. (2006a) "Summer Syndrome" in Litopenaeus stylirostris in New Caledonia: Pathology and epidemiology of the etiological agent, Vibrio nigripulchritudo. Aquaculture 253,105-113

Goarant, C., Reynaud, Y., Ansquer, D., De Decker, S., Saulnier, D. and Le Roux, F. (2006b) Molecular epidemiology of Vibrio nigripulchritudo, a pathogen of cultured penaeid shrimp (Litopenaeus stylirostris) in New Caledonia. Syst. Appl. Microbiol. 29, 570-580

Goarant, C., Reynaud, Y., Ansquer, D., De Decker, S. and Merien, F. (2007) Sequence polymorphism-based identification and quantification of Vibrio nigripulchritudo at the species and subspecies level targeting an emerging pathogen for cultured shrimp in New Caledonia. J. Microbiol. Meth. 70, 30-38

Hacker, J., Hochhut, B., Middendorf, B., Schneider, G., Buchrieser, C., Gottschalk, G., and Dobrindt, U. (2004) Pathogenomics of mobile genetic elements of toxigenic bacteria. Int J Med Microbiol 293, 453-61.

Hsieh, J.L., Fries, J.S., and Noble, R.T. (2008) Dynamics and predictive modelling of Vibrio spp. in the Neuse River Estuary, North Carolina, USA. Environ Microbiol. 10, 57-64

Islam, M.S., Miah, M.A., Hasan, M.K., Sack, R.B. and Albert, M.J. (1994) Detection of nonculturable Vibrio cholerae $\mathrm{O} 1$ associated with a cyanobacterium from as aquatic environment in Bangladesh. Trans R Soc Trop Med Hyg 88, 298-299.

Kaneko, T. and R. R. Colwell. (1978). The annual cycle of Vibrio parahaemolyticus in Chesapeake bay. Microbial Ecology 4, 135-155.

Kautsky, N., Ronnback, P., Tedengren, M. and Troell, M. (2000) Ecosystem perspectives on management of disease in shrimp pond farming. Aquaculture 191, 145-161

La Rosa, T., Mirto, S., Marino, A., Alonzo, V., Maugeri, T.L., and Mazzola, A. (2001) Heterotrophic bacteria community and pollution indicators of mussel--farm impact in the Gulf of Gaeta (Tyrrhenian Sea). Mar Environ Res. 52, 301-21.

Lemonnier, H., Herbland, A., Salery, L. and Soulard, B. (2006) "Summer syndrome" in Litopenaeus stylirostris grow out ponds in New Caledonia: zootechnical and environmental factors. Aquaculture 261, 1039-1047

Lipp, E. K., A. Huq, and R. R. Colwell. (2002). Effects of global climate on infectious disease: the cholera model. Clin Microbiol Reviews 15, 757-770.

Lorenzen, C.J. and Jeffrey, S.W. (1980) Determination of chlorophyll and phaeopigments spectrophotometric equations. Limnol. Oceanogr. 12, 343-346

Mermoud, I., Costa, R., Ferré, O., Goarant, C. and Haffner, P. (1998) "Syndrome 93" in New Caledonia outdoor rearing ponds of Penaeus stylirostris: history and description of three major outbreaks. Aquaculture 164, 323-335 
Pruzzo, C., Huq, A., Colwell, R. R. and Donelli, G. (2005) Pathogenic Vibrio species in the Marine and Estuarine Environment. In: Oceans and Health: Pathogens in the Marine Environment. ed. Belckin, Colwell. Springer, New York, pp. 217-252

Reynaud, Y., Saulnier, D., Mazel, D., Goarant, C. and Le Roux, F. (2008) Correlation between detection of a plasmid and high-level virulence of Vibrio nigripulchritudo, a pathogen of the shrimp Litopenaeus stylirostris. Appl. Environ. Microb. 74, 3038-3047

Sakai, T., Hirae, T., Yuasa, K., Kamaishi, T., Matsuyama, T., Miwa, S., Oseko, N. and lida, T. (2007) Mass mortality of cultured Kuruma prawn Penaeus japonicus caused by Vibrio nigripulchritudo. Fish Pathol. 42, 141-147.

Tamplin, M.L., Gauzens, A.L., Huq, A., Sack, D.A. and Colwell, R.R. (1990) Attachment of Vibrio cholerae serogroup $\mathrm{O} 1$ to zooplankton and phytoplankton of Bangladesh waters. Appl Environ Microbiol 56, 1977-1980.

Wabete, N., Chim, L., Lemaire, P. and Massabuau, J.-C. (2008) Life on the edge: physiological problems in penaeid prawns Litopenaeus stylirostris living on the low side of their thermopreferendum. Mar. Biol. 154, 403-412

\section{Tables}

Table I. Reference strains used in this study

\begin{tabular}{|c|c|}
\hline Species & Strain \\
\hline Vibrio nigripulchritudo & CIP $103195^{\top}$ \\
\hline Vibrio penaeicida & $\mathrm{KH}-1^{\top}\left(=\mathrm{IFO} 15660^{\top}\right)$ \\
\hline Vibrio penaeicida & CRB AM101 \\
\hline Vibrio orientalis & LMG 7.897 \\
\hline Vibrio nereis & LMG 3.895 \\
\hline Vibrio splendidus & CIP 102.893 \\
\hline Vibrio alginolyticus & ATCC $17.749^{\top}$ \\
\hline Vibrio harveyi & CIP $103192^{\top}$ \\
\hline Vibrio fluvialis & CIP $103.355^{\top}$ \\
\hline Vibrio aesturianus & CIP $102971^{\top}$ \\
\hline Vibrio damsela & CIP $102.761^{\top}$ \\
\hline Vibrio orientalis & LMG 7.897 \\
\hline \multicolumn{2}{|c|}{$\begin{array}{l}\text { CIP = Collection de I'Institut Pasteur, Paris, France; IFO = Institute for Fermentation, Osaka, } \\
\text { Japan ; CRB = Centre de Ressources Biologiques, Laboratoire Génétique et Pathologie, } \\
\text { Ifremer, La Tremblade, France ; LMG = Belgian Coordinated Collection of Microorganisms, } \\
\text { Laboratory voor Microbiologie, Universiteit, Gent, Belgium. }\end{array}$} \\
\hline
\end{tabular}


Table II. Vibrio nigripulchritudo field isolates used and recent results on their virulence and genetic characterization.

\begin{tabular}{|c|c|c|c|c|c|}
\hline $\begin{array}{l}\text { Vibrio } \\
\text { nigripulchritu } \\
\text { do strains }\end{array}$ & $\begin{array}{l}\text { SFn1, group : } \\
\text { SFn1, AgMn7, } \\
\text { SFn27, } \\
\text { SFn135, } \\
\text { POn3, POn19. }\end{array}$ & $\begin{array}{l}\text { Fn13 group : } \\
\text { Fn13, SVn7, } \\
\text { SVn8, sVn9. }\end{array}$ & $\begin{array}{l}\text { BDn1 group : } \\
\text { BDn1, BLFn1, } \\
\text { BLFn2, ENn2, } \\
\text { AQn1, AQn2, } \\
\text { Wn1, Wn3. }\end{array}$ & $\begin{array}{l}\text { SO65 group : } \\
\text { SO65, AM102, } \\
\text { AM115, AMn3, } \\
\text { AMn4. }\end{array}$ & $\begin{array}{l}\text { SFn118 group } \\
: \quad \text { SFn118, } \\
\text { POn4, POn13, } \\
\text { SOn2, AgMn1, } \\
\text { AgMn3, ESn2, } \\
\text { Fn2, POn12, } \\
\text { ENn1, SOn1. }\end{array}$ \\
\hline $\begin{array}{l}\text { Virulence in } \\
\text { experimental } \\
\text { infection }\end{array}$ & $\begin{array}{l}\text { Highly } \\
\text { pathogenic } \\
\text { (Goarant et al., } \\
2006 \mathrm{a} \text { and } \\
2006 \mathrm{~b} \text { and } \\
\text { Reynaud et al., } \\
2008 \text { ) } \\
\end{array}$ & $\begin{array}{l}\text { Highly } \\
\text { pathogenic } \\
\text { (this study) }\end{array}$ & $\begin{array}{l}\text { Moderately } \\
\text { pathogenic } \\
\text { (Goarant et al., } \\
2006 a \text { and } \\
2006 \mathrm{~b} \text { and } \\
\text { Reynaud et al., } \\
\text { 2008) }\end{array}$ & $\begin{array}{l}\text { Moderately } \\
\text { pathogenic } \\
\text { (Goarant et al., } \\
2006 \mathrm{~b} \text { and } \\
\text { unpublished } \\
\text { results) }\end{array}$ & $\begin{array}{l}\text { Non virulent } \\
\text { (Goarant et al., } \\
2006 a \text { and } \\
2006 b \text { ) }\end{array}$ \\
\hline $\begin{array}{l}\text { Genotypic } \\
\text { characterization } \\
\text { (Goarant et al., } \\
\text { 2006b) }\end{array}$ & $\begin{array}{l}\text { Summer } \\
\text { syndrome } \\
\text { genotype }\end{array}$ & $\begin{array}{l}\text { Summer } \\
\text { syndrome } \\
\text { genotype }\end{array}$ & $\begin{array}{l}\text { Summer } \\
\text { syndrome } \\
\text { genotype }\end{array}$ & $\begin{array}{l}\text { Different } \\
\text { genotype }\end{array}$ & $\begin{array}{l}\text { Several } \\
\text { different } \\
\text { genotypes }\end{array}$ \\
\hline $\begin{array}{l}\text { Plasmid analysis } \\
\text { and macroarray } \\
\text { results (Reynaud } \\
\text { et al, 2008) }\end{array}$ & $\begin{array}{l}\text { All pSFn1 } \\
\text { markers } \\
\text { detected by } \\
\text { macro-array }\end{array}$ & $\begin{array}{l}\text { No } \\
\text { available }\end{array}$ & $\begin{array}{lr}\text { Some pSFn1 } \\
\text { markers not } \\
\text { detected by } \\
\text { macro-array }\end{array}$ & $\begin{array}{ll}\text { No } & \text { data } \\
\text { available }\end{array}$ & $\begin{array}{l}\text { No plasmid } \\
\text { markers }\end{array}$ \\
\hline $\begin{array}{l}\text { PCR results from } \\
\text { this study using } \\
\text { pSFn1-specific } \\
\text { primers pSFn1- } \\
6020 \text { and pSFn1- } \\
6974\end{array}$ & Positive & Positive & Negative & Negative & Negative \\
\hline $\begin{array}{l}\text { Suggested } \\
\text { diagnosis in terms } \\
\text { of Summer } \\
\text { syndrome hazard }\end{array}$ & High risk & High risk & Medium risk & Medium risk & Low risk \\
\hline
\end{tabular}


Table III. Sediment quality. Mean (standard error; sample size) of samples collected over the entire pond.

\begin{tabular}{lll}
\hline Sampling date & Day 56 & Day 107 \\
\hline Temperature $\left({ }^{\circ} \mathrm{C}\right)$ & $23.8(0.1 ; 42)$ & $29.7(0.1 ; 42)$ \\
\hline $\mathrm{pH}$ & $7.2(0.1 ; 42)$ & $\mathbf{6 . 9}(0.1 ; 42)$ \\
\hline Chlorophyll Concentration $\left(\mu \mathrm{g} . \mathrm{g}^{-1}\right.$ dry weight) & $26(4 ; 41)$ & $\mathbf{6}(1 ; 42)$ \\
\hline Organic matter (\%) & $4.5(0.3 ; 37)$ & $4.9(0.2 ; 40)$ \\
\hline Water content $(\%)$ & $25.6(0.6 ; 42)$ & $25.1(0.7 ; 42)$ \\
\hline Total heterotrophic flora $\left(\mathrm{CFU} . \mathrm{g}^{-1}\right.$ dry weight $)$ & $5 \times 10^{7}\left(5 \times 10^{6} ; 84\right)$ & $3 \times 10^{7}\left(3 \times 10^{6} ; 62\right)$ \\
\hline
\end{tabular}


Figure 1. Culturable total heteretrophic bacteria (log CFU.g 1dry weight) of pond samples at two sampling dates. Circles represent samples from which presumptive Vibrio nigripulchritudo were detected. Darker areas represent higher bacterial counts. Pond dimensions are in meters.

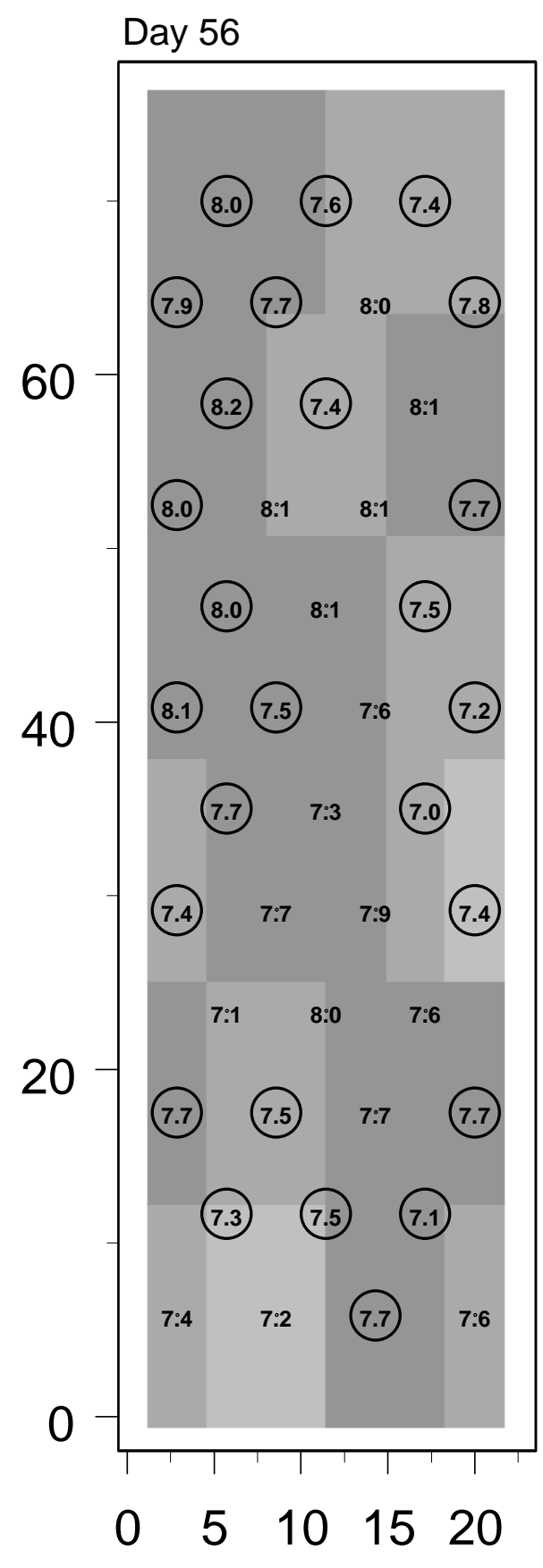


Figure 2. Direct PCR detection of Vibrio nigripulchritudo (circles), Summer Syndrome genotype (squares) and plasmid pSFn1 (crosses) at two sampling dates. Summer Syndrome genotype detection was quantitative and four classes are identified by squares of four sizes and shades of grey (> $4 \times 10^{3}, 2 \times 10^{3}-4 \times 10^{3},<2 \times 10^{3}$ Vibrio. $g^{-1}$ wet weight, not detected.) Pond dimensions are in meters.

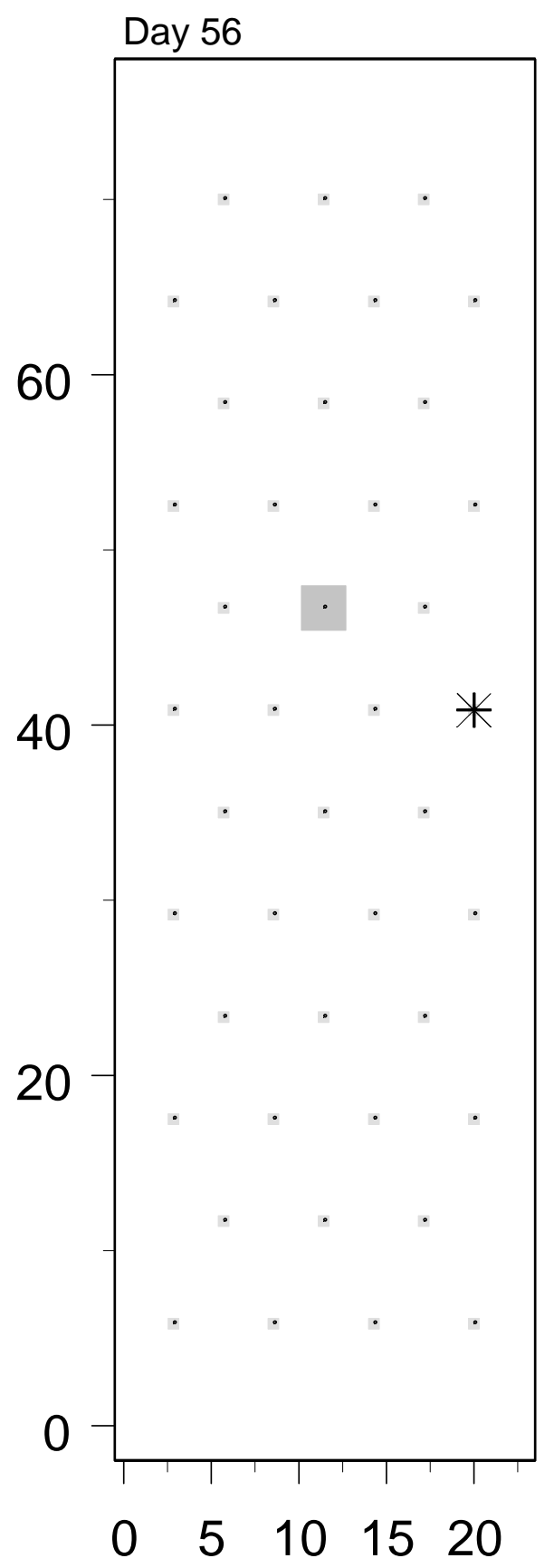


Day 56

Figure 3. Enriched PCR detection of Vibrio nigripulchritudo (circles) and plasmid pSFn1 (crosses) at two sampling dates. Pond dimensions are in meters.

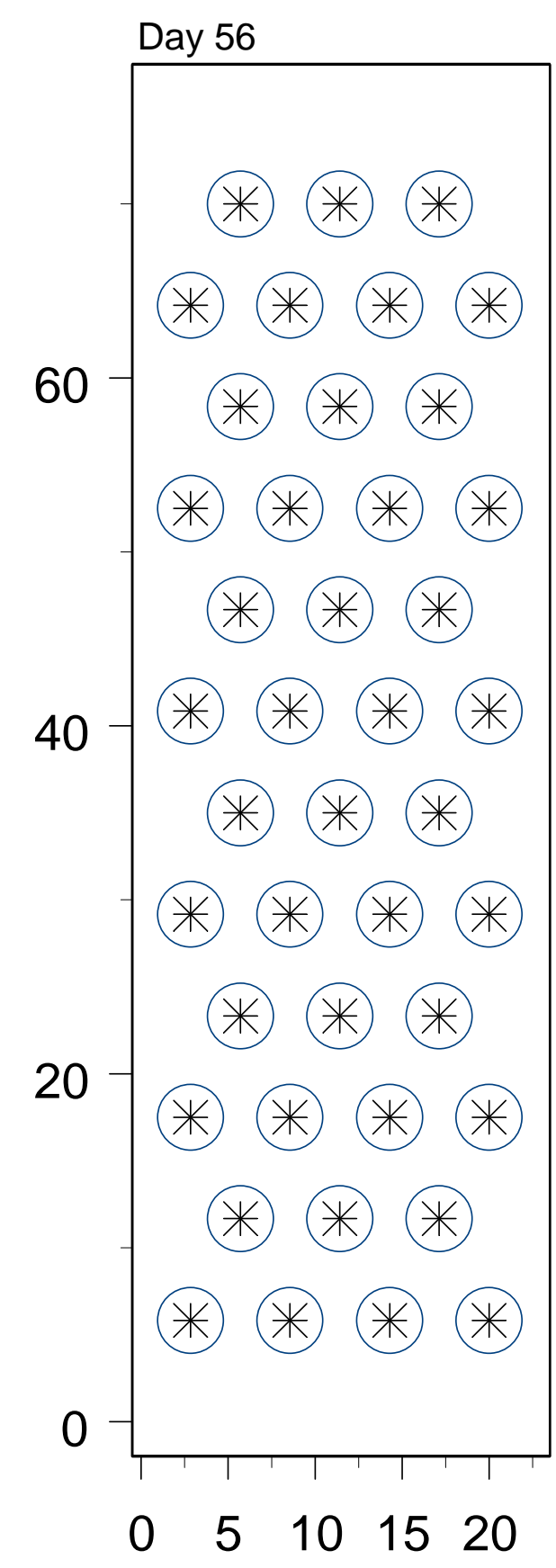

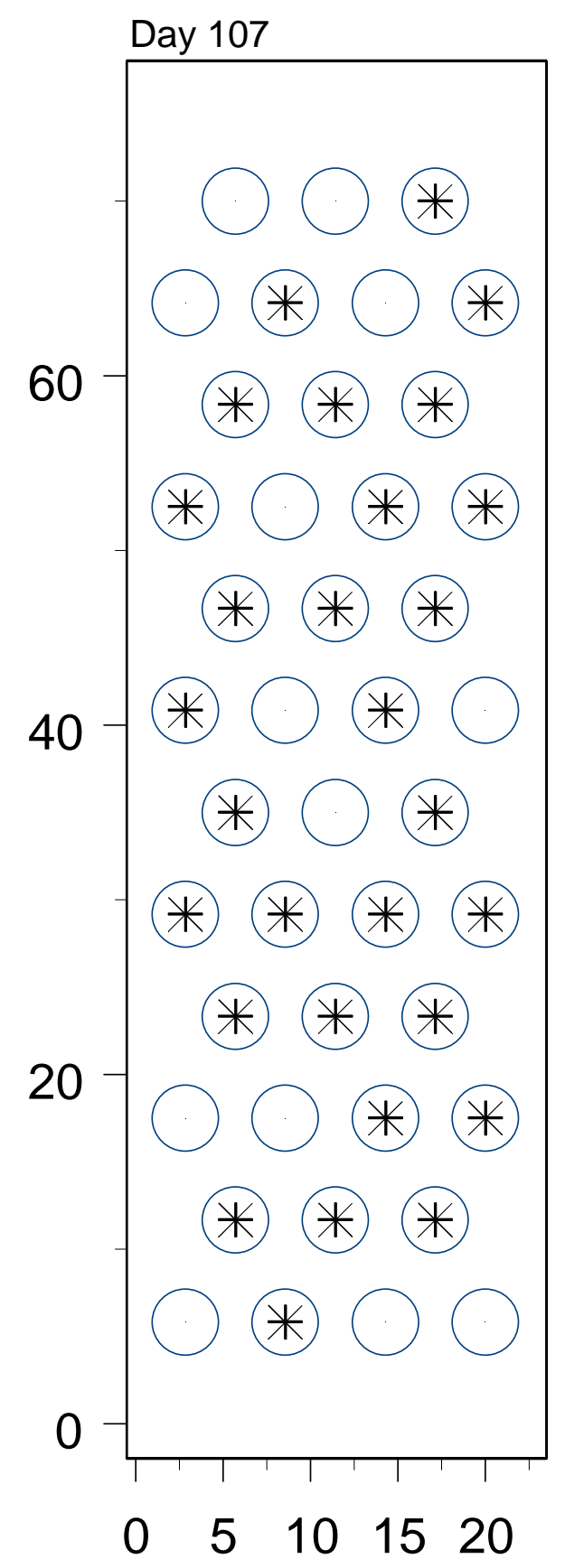

